\title{
Catarse: aproximações conceituais com o ensino da arte
}

Priscila de Souza Chisté Leite

Professora do Instituto Federal do Espírito Santo

\section{Resumo}

A catarse é considerada por muitos autores como um "efeito" ligado a um processo que leva à tomada de consciência. Que "efeito" é esse? Por quem foi sistematizado? Quais abordagens foram construídas a partir desse conceito? Qual a sua relação com a educação e com os espaços escolar e expositivo? O artigo em tela pretende refletir, por meio de pesquisa bibliográfica, sobre essas questões ao revisitar o conceito de catarse a partir de autores como Aristóteles, Vigotski, Jauss e, em especial, Lukács. Busca relacionar as ideias desse esteta húngaro ao campo da educação e, principalmente, ao ensino da arte.

Palavras-Chave: arte; catarse; educação.

\begin{abstract}
The catharsis is considered by many authors as an "effect" tied to a process which leads to awareness. What "effect" is that? By whom was systematized? What approaches were built from that concept? What is your relationship with education and with the school and exhibition spaces? This article intends to screen reflect, by means of bibliographical research, on these issues to revisit the concept of catharsis from authors such as Aristotle, Vygotsky, Jauss and, in particular, Lukács. It searches to relate the ideas of this Hungarian aesthete to the field of education and, especially, to the teaching of art.
\end{abstract}

Keywords: art; catharsis; education.

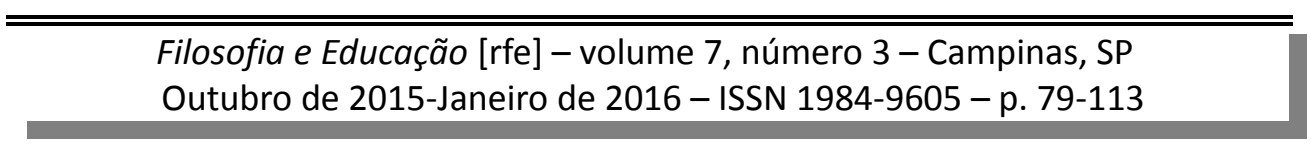




\section{Introdução}

arte e as reflexões que ela provoca contribuem para a formação
crítica do indivíduo. Entendemos que um encontro significativo
com a obra de arte, elaborado na escola e/ou no espaço expositivo, torna possível que o indivíduo reconheça sua própria essência, sua história no processo de desenvolvimento do ser humano. A arte provoca a catarse, que é vista por muitos autores como um "efeito" ligado a um processo que leva à tomada de consciência. Que "efeito" é esse? Por quem foi sistematizado? Quais abordagens foram construídas a partir desse conceito? Qual sua relação com a educação e com os espaços escolar e expositivo?

De modo a contribuir com essas discussões pretendemos compartilhar algumas reflexões teóricas sobre o conceito de catarse e sua relação com o ensino da arte enfatizando a importância dos processos catárticos.

Para tanto, apresentaremos o artigo em três seções. Na primeira, abordaremos a questão da arte e seu ensino, ao reforçar a importância para a formação humana. Na segunda seção, explicitaremos considerações sobre o conceito de catarse partir de Aristóteles, Vigotski, Jauss e Luckács. Já na terceira seção, buscaremos aproximar o conceito de catarse luckacsiano ao trabalho educativo, mais especificamente ao ensino da arte, seja na escola e/ou no espaço expositivo.

\section{A arte e seu ensino}

Entendemos que o ensino da arte constitui-se como fundamental integrante no processo de formação do indivíduo, pois a relação entre a obra de arte e o sujeito permite o desencadeamento de um processo reflexivo fundamental na construção social do indivíduo. Possibilita que o sujeito participe de vivências estéticas que o estimule a repensar seu cotidiano, colaborando 
com a ampliação de seu conhecimento de mundo, do outro e de si. No mundo contemporâneo, onde o poder é exercido, muitas vezes, pela mídia e pela publicidade, somos desafiados a ler imagens que se colocam como reconstituições simbólicas do real fetichizado. Portanto, nesse contexto, consideramos que o processo reflexivo originado pela relação do sujeito com a obra de arte é fundamental para colaborar com a transformação das estruturas alienantes, proporcionando uma nova atitude diante dos acontecimentos cotidianos.

Nesse sentido, a arte precisa ser conhecida e valorizada por todos os indivíduos. Essa produção humana é parte integrante do desenvolvimento da humanidade, capaz de revelar/apresentar o contexto histórico e cultural através de sua materialidade. A arte é produto do trabalho do homem e, por suas particularidades, suscita no receptor, processos catárticos que o fazem pensar sobre sua vida, sobre o mundo e sobre o outro. No espaço expositivo (galerias de arte, museus, centros culturais etc.) e escolar os sujeitos dessa mediação são: o artista e sua obra, o professor, o educador do espaço expositivo e os alunos, assim como outros sujeitos que atravessam a relação arte/receptor.

Portanto, o ensino da arte tem como desafio ampliar e aprofundar a experiência estética do aluno, constituindo-se como fundamental integrante no processo de formação do indivíduo. O encontro significativo com a obra de arte, promovido pela escola e pelo espaço expositivo, torna possível que o indivíduo reconheça sua própria essência, sua história no processo de desenvolvimento do ser humano. Além disso, entender a obra de arte envolve compreendê-la em seu contexto, conhecer a poética do artista e atribuir significados a ela. Significados carregados da vivência do receptor. Esse processo de leitura de imagem envolve também a catarse, que é vista por Lukács (1966) como um "efeito" ligado a um processo que leva à 
tomada de consciência do mundo fetichizado por parte do receptor.

Contudo, além de Lukács, muitos foram os teóricos que se debruçaram sobre o tema. Por isso, na seção seguinte, apresentaremos alguns deles, sabendo que a discussão sobre catarse é muito mais ampla do que a que estamos a sistematizar.

\section{Catarse: definindo o conceito; aproximações}

Nessa seção, buscaremos nos aproximar dos estudos desenvolvidos sobre a catarse a partir de Aristóteles (1992), Vigotski (1999), Jauss (1979) e Lukács (1966). A escolha deve-se ao fato de reincidentemente vê-los no bojo dessa discussão, muitas vezes sendo citados por outros teóricos que se aproximaram desse tema. Com isso, não temos a pretensão de construir uma trajetória histórica desse conceito, apenas elegemos esses autores para apresentar discussões trazidas por eles sobre a catarse.

\section{Uma aproximação aristotélica à catarse}

O conceito de catarse surgiu na cultura ocidental, na Antiguidade. Em alguns textos gregos, ele aparece com o sentido fundamental de limpeza, purificação, purgação ou depuração. Dentre os filósofos dessa época que escreveram sobre a catarse, está Aristóteles que, a fim de definir o conceito de tragédia, refere-se à catarse, para examinar o efeito da tragédia sobre o espectador. Sua definição de catarse constitui a matriz sobre a qual se desenvolveram muitos estudos posteriores sobre esse conceito, aparecendo no texto aristotélico intitulado como "Poética", que data de aproximadamente 350 a.C.. Nessa ocasião, o filósofo descreveu o passado de glória da tragédia ateniense. Assim, a tragédia foi vista como algo extremamente útil para a política, funcionando como um canal emissor de problemas e de reflexões sobre eles. 
O teatro trouxe a possibilidade de o povo ateniense entrar em contato com diferentes questões relativas à existência humana. Como consequência, o cidadão poderia refletir sobre atos e situações que só poderiam ser vivenciados por intermédio da tragédia.

Na tradução de Eudoro de Souza, o trecho da "Poética" que trata do conceito de catarse é o seguinte:

[...] a tragédia é uma mimésis de uma ação nobre, completa e de certa extensão, em linguagem embelezada separadamente pelas diversas formas de cada parte; é mimésis que se realiza por agentes e não por narrativa, e que conduz, através da piedade e do temor, para a purificação [catarse] de tais emoções (ARISTÓTELES, 1992, p. 24, grifo nosso).

O prazer trágico, então, seria uma consequência da participação emocional dos espectadores ao se identificarem com os protagonistas do drama, sentindo por eles piedade.

[...] é que esse prazer estaria assim diretamente associado ao modo mitigado de enfrentar situações terríveis, ou seja, ao alívio produzido em suas almas ao perceberem que o objeto de seu medo é apenas uma imitação e que, por conseguinte, não lhes poderá fazer mal ou a seus próximos. Em outras palavras: dessa experiência mimética, seja na Atenas do século IV a.C., seja em nossos dias, decorreria o prazer trágico propriamente dito. E, muito provavelmente, é exatamente esse tipo de prazer (de origem mimética), experimentado ante uma representação trágica, que Aristóteles considerou como tendo um efeito purificador sobre as emoções (PUENTE, 2002, p. 24). 
Desse modo, ao vivenciar a tragédia, o cidadão era levado a uma experiência profunda, que se processava tanto na identificação, por meio da qual o espectador se compadecia do protagonista, quanto na rejeição, quando o espectador temia chegar a tais atos realizados pelo mesmo protagonista. Os sentimentos suscitados pela obra são considerados por Aristóteles como o último movimento do espectador da tragédia em sua participação no evento, caracterizando essa relação como uma relação mais ética, de compaixão do espectador pelo sofrimento do herói, afastando-se de um ato estético, de uma relação ativa e criativa do contemplador com a obra.

É importante ressaltar ainda que a edição da Poética só aconteceu em 1508 e sua leitura ficou relegada a literatos que, segundo Veloso (2002), pouco ou nada conheciam do restante das obras de Aristóteles ou que, ainda que conhecessem, não as inseririam no contexto do pensamento aristotélico. Isso favoreceu o surgimento de versões por vezes equivocadas.

\section{Uma aproximação vigotskiana à catarse}

Muitos teóricos ocuparam-se em interpretar e ampliar o conceito de catarse criado por Aristóteles, para o entendimento da tragédia. Um deles foi Vigotski, autor de análises psicológicas profundas, capaz de contestar muitos estudos sobre a psicologia, realizados em sua época. Dentre suas produções acadêmicas, está o livro Psicologia da arte, concluído em 1925, quando o autor tinha 19 anos, e somente publicado na Rússia em 1965.

Nesse livro, o teórico escreve um capítulo chamado "A arte como catarse", no qual busca entender os aspectos biológicos e sociais que envolvem a reação estética. Para ele, a reação estética começa pela via da percepção sensorial, mas não se restringe a ela, pois é preciso que a compreensão da arte parta do sentimento e da imaginação. Segundo o autor,

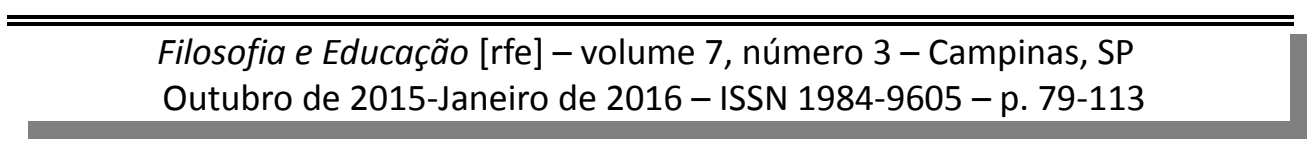


Nossa reação estética se nos revela antes de tudo não como uma reação que economiza mas como reação que destrói a nossa energia nervosa, lembrando mais uma explosão do que uma economia de centavos (VIGOTSKI, 1999, p. 257).

Vigotski (1999) procura desenvolver uma teoria que tenha condição de explicar a relação interna que existe entre o sentimento e os objetos suscetíveis da percepção, apoiado na relação existente entre a fantasia e o sentimento. Para tanto, propõe que “[...] a emoção não se expressa nas reações químicas, pantomímicas, secretórias e somatórias do organismo, mas precisa de certa expressão por meio de nossa fantasia" (Vigotski, 1999, p. 263). Toda a emoção serve-se da imaginação e se reflete numa série de representações e imagens fantásticas, que fazem, às vezes, uma segunda expressão, contudo toda expressão é fortemente referida à realidade, às vivências dos sujeitos concretos.

Vigotski (1999) acredita, no entanto, ser fundamental diferenciar o sentimento comum do sentimento artístico, sendo esse último intensificado pela fantasia. Outro aspecto importante é que as emoções suscitadas pela arte não se manifestam em nenhuma ação externa. $\mathrm{O}$ autor diz que toda obra de arte visa a favorecer certas emoções que, entretanto, não podem se expressar diretamente pela ação da emoção. "As emoções da arte são emoções inteligentes. Em vez de se manifestarem de punhos cerrados e tremendo, resolvem-se principalmente em imagens da fantasia" (Vigotski, 1999, 267). Complementa argumentando que a arte suscita, simultaneamente, emoções opostas, operando pelo princípio da antítese. É como se a arte despertasse uma série de sentimentos opostos entre si e provocasse um curto-circuito e a destruição desses sentimentos. Podemos entender isso como o verdadeiro 
efeito da obra de arte, a catarse, conceito compartilhado por Vigotski com outros autores:

Entendemos com Lessing, a catarse como efeito moral da tragédia, a "conversão das paixões em inclinações virtuosas" ou, com E. Muller, como passagem do desprazer para o prazer, e assim temos a interpretação de Bernays, segundo quem essa palavra significa cura e purificação no sentido médico, ou a opinião de Zeller, para quem a catarse representa uma tranquilização da emoção. Seja como for, tudo isso traduzirá da forma mais incompleta possível, o sentido que queremos atribuir a essa palavra (VIGOTSKI, 1999, p. 269).

Apesar da imprecisão do significado e do conteúdo do conceito de catarse, o autor não conhece outro termo que traduza, com tanta plenitude e clareza, a reação estética, reação em que as emoções angustiantes e desagradáveis são submetidas a certa descarga nervosa que as transformam em contrários, reduzindo a reação estética à catarse, à complexa transformação dos sentimentos (Vigotski,1999).

Preocupado em esclarecer suas ponderações sobre a catarse, o psicólogo russo resume suas considerações sobre o assunto ao elaborar o seguinte texto, voltado para a composição de uma fórmula estética:

Poderíamos dizer que a base da reação estética são as emoções suscitadas pela arte e por nós vivenciadas com toda realidade e força, mas encontram a sua descarga naquela atividade da fantasia que sempre requer de nós a percepção da arte. Graças a esta descarga central, retém-se e recalca-se extraordinariamente o aspecto motor externo da emoção, e começa a nos parecer que apenas experimen-

Filosofia e Educação [rfe] - volume 7, número 3 - Campinas, SP

Outubro de 2015-Janeiro de 2016 - ISSN 1984-9605 - p. 79-113 
tamos sentimentos ilusórios. É nessa unidade de sentimento e fantasia que se baseia qualquer arte. Sua peculiaridade imediata consiste em que, ao nos suscitar emoções voltadas para sentidos opostos, só pelo princípio da antítese retém a expressão motora das emoções e, ao pôr em choque impulsos contrários, destrói as emoções do conteúdo, as emoções da forma, acarretando a explosão e a descarga da energia nervosa (VIGOTSKI, 1999, p. 272).

Tendo em vista o caráter inovador da discussão sobre a psicologia da arte, acreditamos que, com esse texto, Vigotski (1999) contribui para o entendimento da catarse, principalmente sobre a atuação desse processo na mente humana, mas esboça, de forma incipiente, a vinculação desse conceito à dimensão sócio-histórica. Percebemos que esse estudo privilegia uma abordagem do conceito de catarse como um processo psicológico.

Cabe aqui, então, trazer questões levantadas pelo amigo e parceiro teórico de Vigotski, Leóntiev (1997), sobre essa discussão. Segundo ele, Vigotski (1999) buscou, com esse estudo, oferecer uma análise objetivomaterialista das emoções humanas que surgem ao se interpretar a obra de arte. Porém, ao tentar analisar objetivamente as emoções provocadas pelas obras de arte, não obteve êxito, tendo em vista que, nos anos da década de 1920, as ciências psicológicas ainda não tinham alcançado um nível satisfatório de desenvolvimento. Sendo assim, Leóntiev (1997) considera inacabadas e unilaterais as teorizações trazidas em Psicologia da arte. Essa opinião vem confirmar o motivo de essa obra não ter sido publicada em vida pelo próprio Vigotski, que também a considerava inacabada. Para Leóntiev, os problemas que estavam postos no campo da psicologia da arte e a impossibilidade de resolvê-los fizeram com que Vigotski passasse a se dedicar à psicologia geral. Valsiner e Veer (1996) concordam que o desejo de Vigotski em aprofundar suas teorizações sobre os procedimentos 
conscientes implicados na criação, apreciação artística e sobre a especificidade psicológica da reação estética o conduziu ao estudo exaustivo da psicologia geral.

\section{Uma aproximação jaussiana à catarse}

Dando continuidade à nossa explanação sobre a catarse, observamos que os estudos que envolvem esse conceito intensificam-se no século XX, amparados principalmente em filósofos, como Kant e Hegel. Uma importante contribuição para a reflexão sobre os processos receptivos na abordagem estética é feita pelos teóricos da Escola de Konstanz, na Alemanha, em pesquisas realizadas entre 1967 e 1970. Esses estudos colocam-se como resposta ao estruturalismo e propõem uma Estética da Recepção. Seus principais precursores foram Wolfgang Iser e Hans Robert Jauss. Para eles, a Estética da Recepção deveria ser entendida como

[...] o tipo de indagação em torno da obra de arte que tematiza o receptor, o leitor, o observador como parte fundamental da práxis da arte; estética da recepção é o trabalho de estudo teórico que indaga sobre o papel ativo desse integrante da práxis artística (GONÇALVES, 2004, p. 83).

Hans Robert Jauss pontua que, durante um longo período, a teoria estética se preocupou pouco com a experiência estética. As reflexões filosóficas sobre a arte tratavam de assuntos polares, como a arte e a natureza; o belo, a verdade e o bem; a forma e o conteúdo; a imitação e a criação; entre outras. Para esse autor, ao assumirmos a arte como atividade humana produtora, receptiva e comunicativa, é de suma importância esclarecer a questão da experiência estética. Segundo ele, Aristóteles, na Antiguidade, e Kant, na 
Idade Moderna, foram um dos poucos que se detiveram a essa questão, mas não foram capazes de formar uma tradição acerca da experiência estética. Com Hegel ficou definido que o belo era o aparecimento sensível da ideia, e esse pressuposto abriu caminho para as teorias histórico-filosóficas da arte. Mas, mesmo assim, as teorias se fundamentavam em entender a arte como a história das obras e de seus autores, ou seja, “[...] passou-se a considerar somente o lado produtivo da experiência estética, raramente o receptivo e quase nunca o comunicativo" (Jauss, 1979a, p. 44).

Embasado na hermenêutica ${ }^{1}$, Jauss afirma ser fundamental diferenciar os dois modos de recepção: “[...] aclarar o processo atual em que se concretizam o efeito e o significado do texto para o leitor contemporâneo e, de outro, reconstruir o processo histórico pelo qual o texto é sempre recebido e interpretado diferentemente, por leitores de tempos diversos" (JAUSS, 1979a, p. 46). O fundamental, então, é comparar o efeito atual de uma obra de arte com o desenvolvimento histórico de sua experiência, formando o juízo estético com base nas duas instâncias de efeito e recepção. Para ele, somente a hermenêutica da pergunta e da resposta daria conta do processo dinâmico de produção e recepção e da relação dinâmica entre o autor, a obra e o público. Sobre esse assunto, Jauss (1979a, p. 49) complementa afirmando que,

[...] para a análise da experiência do leitor ou da 'sociedade de leitores' de um tempo histórico determinado, necessita-se diferenciar, colocar e estabelecer a comunicação entre dois lados da relação

1 A palavra hermenêutica é derivada do termo grego hermeneutike. É a ciência que estabelece os princípios, leis e métodos de interpretação. Em sua abrangência, trata da teoria da interpretação de sinais, símbolos de uma cultura e leis. A divisão da hermenêutica é reconhecida como geral e específica: a geral é aquela que se aplica à interpretação de qualquer obra escrita; a específica é aquela que se aplica a determinados tipos de produção literais, tais como: leis, histórias, profecias e textos literários.

Filosofia e Educação [rfe] - volume 7, número 3 - Campinas, SP

Outubro de 2015-Janeiro de 2016 - ISSN 1984-9605 - p. 79-113 
texto e leitor. Ou seja, entre o efeito, como momento condicionado pelo texto, e a recepção, como momento condicionado pelo destinatário, para a concretização do sentido como duplo horizonte - interno ao literário, implicado pela obra, e o mundivivencial, trazido pelo leitor de uma determinada sociedade. Isso é necessário a fim de se discernir como a expectativa e a experiência se desencadeiam e para saber se, nisso, se produz um momento de nova significação.

Como foi visto, Jauss (1979a) explicita que a experiência estética é resultado do relacionamento da obra de arte e com o leitor. Essa experiência acontece quando estão envolvidas, concomitantemente, três funções da ação humana na atividade estética: a poiésis, a aisthésis e a kátharsis. Tendo em vista o foco do estudo em questão, vamos nos concentrar em um dos três aspectos centrais da teoria da experiência estética desse autor: a kátharsis. ${ }^{2}$

Ao estudar esse conceito, Jauss (1979a), apesar de recorrer aos estudos clássicos sobre a kátharsis, atribui-lhe um sentido novo. Ele a define como a função comunicativa da expressão estética. Para o autor, a função comunicativa da arte ocorre quando existe um processo de identificação do leitor com a obra. Segundo Jauss (1979a), é justamente na dinâmica de identificação que se processam as ações, como se, ao se identificar, o sujeito receptor se aliviasse das pressões vindas da ordem jurídica e das instituições sociais. Esse efeito é um libertar-se de e para alguma coisa, mas, ao mesmo tempo, o processo de identificação pode ocasionar a assimilação de valores e convenções dominantes, que colaboram com as conservações das normas impostas. Mesmo sabendo disso, Jauss interessa-se pelo potencial emancipatório da experiência estética. Preocupa-se em propor uma teoria da experiência estética que problematize as questões que se relacionam com o con-

2 Optamos por utilizar a grafia escolhida pelo autor atribuída à catarse.

Filosofia e Educação [rfe] - volume 7, número 3 - Campinas, SP

Outubro de 2015-Janeiro de 2016 - ISSN 1984-9605 - p. 79-113 
texto. Sendo assim, Jauss questiona como a experiência estética pode recobrar sua importância em uma época em que a arte é tida como expressão de uma elite, além de estar envolta pela indústria cultural. Problematiza a questão ao perguntar: como valorizar tal experiência tendo em vista que essa é percebida como algo pobre em frente a métodos mais em voga, como a semiótica, a teoria da informação, entre outros?

Buscando uma teoria que desse suporte aos seus questionamentos, Jauss (1979a) posiciona-se em frente a Kant, ${ }^{3} \mathrm{em}$ sua Teoria do Juízo do Gosto, encontrando também nela alguns elementos que permitem conceber a função comunicativa da experiência estética, a kátharsis.

De acordo com Rego (2006), na terceira crítica, Kant define o juízo como a faculdade de pensar um particular contido sob um universal. Isso significa que, se conhecemos, se avaliamos moralmente, se experimentamos agradabilidade e se contemplamos esteticamente a obra de arte, a cada uma dessas realizações corresponde um modo possível de se referir a um particular. Isso significa que um princípio universal contém em si uma pluralidade de particulares.

Kant (apud Rego, 2006) procura, em sua crítica, chegar a um fundamento de determinação da avaliação estética pertencente ao que todos os sujeitos têm em comum: "Somente se isso existir temos direito de, diante de algo que julgamos belo, aventar a possibilidade de estarmos julgando universalmente e não idiossincraticamente" (Rego, 2006, p. 179).

Em síntese, chega-se à conclusão de que é no ato do juízo reflexivo,

3 A base do pensamento kantiano está firmada em uma concepção filosófica idealista, com viés metafísico. Essa teoria resolve o problema fundamental da relação entre o ser e o pensar, fazendo da consciência, do espírito, o dado primário, original. O Idealismo considera o mundo como encarnação da consciência, da "Ideia Absoluta", do "Espírito Universal". Somente a consciência teria existência real e o mundo material, o ser e a natureza seriam apenas reflexo da ideia, das sensações, das representações e dos conceitos. O Idealismo está, de modo geral, estreitamente ligado à religião e leva, de uma ou de outra forma, à pressuposição de um Criador, portanto, da relação Criador-Criatura.

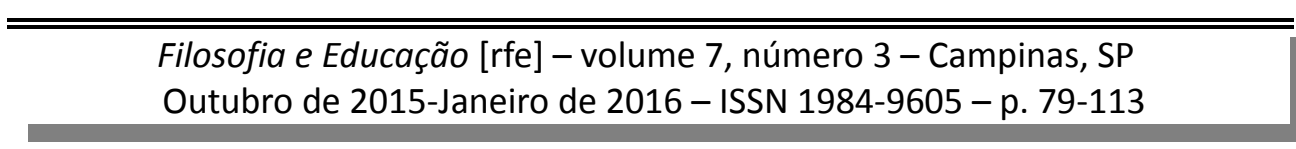


que é técnico, que é arte, que é criativo, que a liberdade pode vir a atuar na natureza. É pelo poder criativo que o sujeito encontra a unidade do mundo em que vive, garantindo que a sua liberdade seja atuante. Pode-se dizer que é pela criação que a liberdade atua, é por ser criativo que o homem é livre, ou seja, atua com sua liberdade no mundo.

Valendo-se dessa teoria, Jauss (1979b) conceitua a kátharsis como “aquele prazer dos afetos provocados pelo discurso ou pela poesia, capaz de conduzir o ouvinte e o espectador tanto à transformação de suas convicções, quanto à libertação de sua psique" (Jauss, 1979b, p. 80-81). O autor ainda coloca que, como experiência estética comunicativa básica, a kátharsis corresponde tanto à tarefa prática da arte como função social, pois serve como mediadora, inauguradora e legitimadora de normas de ação, quanto à determinação ideal de toda arte autônoma, que busca libertar o espectador dos interesses práticos e das implicações de seu cotidiano, a fim de levá-lo, pelo prazer do outro, para a liberdade estética de sua capacidade de julgar (Jauss, 1979b, p. 81).

Sobre essa conceituação, pode-se pensar que a kátharsis abarca o efeito ético e moral da experiência estética, pois, quando interpretamos nossas necessidades recorrendo à mediação das obras de arte, mobilizamos toda a esfera do "prático", numa dinâmica em que normas de ação e normas de avaliação remetem umas às outras. Sendo assim, o efeito ético da experiência estética, então, é capaz de promover em cada um de nós uma universalização individualizante, uma percepção de si mesmo na integração com o todo. "Trata-se daquele momento em que experimentamos uma espécie de elevação da nossa singularidade à humanidade como um universal concreto, na medida em que gozamos no nosso íntimo o que coube em sorte a toda humanidade" (Barbosa, 2002b, p. 99). A experiência estética é capaz de suscitar a kátharsis moral, nutrindo discursos prático-morais que dizem respei-

Filosofia e Educação [rfe] - volume 7, número 3 - Campinas, SP

Outubro de 2015-Janeiro de 2016 - ISSN 1984-9605 - p. 79-113 
to a cada um e, ao mesmo tempo, a todos. Portanto, a experiência estética pode fomentar, ou nos educar, para esse efeito de distanciamento ou de estranhamento, pelo qual visamos ao que diz respeito a cada um, mas na medida de todos.

Em Kant (apud Rego, 2006) e também em Jauss (1979a, 1979b), a relação obra/receptor se dá pela razão. A racionalidade e, nessa perspectiva, o domínio sobre a moral (ética) são premissas dessas abordagens, são as bases epistemológicas sobre as quais se assenta a reflexão sobre o mundo. $\mathrm{O}$ indivíduo, como vivenciador de um processo único, e a hermenêutica, como experiência existencial, são as bases dessa abordagem. Isso significa que trazem contribuições ao debate, quando dimensionam o sujeito como uma parte importante no processo. Concordamos com essa última colocação. Contudo, o limite de Kant é o princípio da contradição. Questões de conflito não são resolvidas unicamente no âmbito do indivíduo, da racionalidade e do juízo moral, mas implicam também sua articulação com o coletivo de seu tempo, seu contexto.

\section{Uma aproximação lukacsiana à catarse}

A catarse se apresenta de forma recorrente entre várias abordagens: médicas, estéticas, psicológicas, antropológicas, ligadas ou não à metafísica. Porém, a categoria catarse toma uma dimensão particular na perspectiva do Materialismo Histórico-Dialético, e traz contribuições fundamentais para o presente artigo.

O materialismo histórico considera a matéria como a base do desen- 
volvimento do mundo, e o pensamento como o reflexo filosófico ${ }^{4}$ da relação do ser com o mundo. Ao colocar na base do mundo diversos elementos materiais, consideram-no como um todo unido, como um processo de mudanças e transformações permanentes.

Marx foi um dos estudiosos que contribuíram para a fundamentação dessa concepção de mundo, a partir do pensamento de que a matéria em perpétuo movimento é o princípio de todas as coisas. Com essa preocupação, Marx dá a essa teoria um caráter material, considerando que os homens se organizam na sociedade para a produção e a reprodução da vida, e também um caráter histórico, tendo em vista que eles se organizam conforme a sua história. Essa materialidade histórica pode ser compreendida a partir das análises realizadas sobre uma categoria considerada central: o trabalho. Segundo essa concepção, o trabalho é o elemento que impulsiona o desenvolvimento humano, "é a atividade pela qual o homem domina a natureza; é a atividade pela qual o homem se cria a si mesmo" (Konder, 1998, p. 29).

Dentre outras tantas produções do homem, está a arte, que é entendida, por essa teoria, também como produto do trabalho humano. Portanto, o Materialismo Histórico-Dialético representa uma possibilidade de compreensão mais ampla do conhecimento histórico e artístico.

Muitos estudiosos apropriaram-se desse referencial para aprofundar seus conhecimentos sobre o mundo. Um deles foi o filósofo Georg Lukács que, a partir dessa perspectiva, se inicia na criação de uma estética marxista, visando a esclarecer alguns problemas concernentes ao campo da arte.

Dentre os livros escritos pelo autor húngaro, está Estética. Essa obra

4 Muitas críticas relativas à teoria do reflexo colocaram-se contra esse conceito, tendo em vista que elas consideraram o reflexo amparado em fenômeno físico, de via única, refletindo a realidade sem modificá-la. Mas, a partir de outros estudos que ampararam esse conceito, fala-se hoje de um reflexo filosófico, considerando todas as interações que envolvem o fenômeno.

Filosofia e Educação [rfe] - volume 7, número 3 - Campinas, SP

Outubro de 2015-Janeiro de 2016 - ISSN 1984-9605 - p. 79-113 
foi elaborada em meados dos anos 1950 e concluída em 1961, sendo publicada, pela primeira vez, na Alemanha, em 1963. Nela o autor busca uma aplicação do marxismo aos problemas estéticos, tendo como principal objetivo buscar a explicitação dos aspectos essenciais e específicos do reflexo estético da realidade. Segundo Duayer (2003), seu ponto de partida para esclarecer o lugar do comportamento estético na totalidade das formas, das atividades humanas e de suas reações espirituais ao mundo externo, à realidade objetiva, será sempre a conduta do homem na vida cotidiana, que considera o começo e o fim de toda atividade humana.

Cabe, a propósito, trazermos para o estudo em tela algumas considerações sobre o conceito de vida cotidiana, pensadas por Agnes Heller, grande estudiosa das ideias de Lukács. Heller (1977) conceitua vida cotidiana como o conjunto de atividades que caracteriza a reprodução dos indivíduos. São atividades voltadas diretamente para a reprodução do indivíduo, por meio das quais, indiretamente, contribuem para a reprodução da sociedade, reproduzidas por seres humanos, sem que, necessariamente, eles mantenham uma relação consciente com essas atividades e com o processo de sua produção. São, por exemplo, constituídas pelos objetos, pela linguagem e pelos usos e costumes, ou seja, os homens produzem a linguagem, os objetos, os usos e costumes de uma forma "natural", "espontânea", por meio de processos que não exigem a reflexão sobre a origem e sobre o significado dessas produções. Segundo Heller, esse significado é dado naturalmente pelo contexto social.

Em contrapartida, as esferas não cotidianas referem-se àquelas atividades que estão diretamente voltadas à reprodução da sociedade, expressando a realidade produzida historicamente pelos homens, ainda que, indiretamente, contribuam para a reprodução do indivíduo, como a arte e a ciência. Ligado a isso, é importante colocar que, nessa concepção, a reprodução da 
sociedade é considerada também como a reprodução das contradições que permeiam a sociedade. Segundo a autora, uma das contradições refere-se ao fato de que, por um lado, a sociedade capitalista forma o indivíduo, reduzindo-o a alguém que ocupa um lugar na divisão social do trabalho e, por outro lado, essa mesma sociedade produz, contraditoriamente, no indivíduo, necessidades de ordem superior, que apontam a formação de um indivíduo que, pela sua inserção consciente nos sujeitos coletivos, mantém uma relação consciente com sua vida cotidiana, mediatizada pela relação também consciente com a arte, ciência, filosofia, moral e política (Duarte, 1996).

Heller (1977) mostra também que não há, necessariamente, alienação no fato de a vida possuir, como uma das características, a unidade imediata entre pensamento e ação, o pragmatismo. Segundo ela, não podemos fundamentar teoricamente a grande heterogeneidade de tarefas que temos diante de nós na vida cotidiana. Ocorre que isso não é obrigatoriamente alienado e alienante; assim se torna quando os homens se mostram incapazes de reconhecer as situações em que é necessário suspender o pragmatismo da vida cotidiana. É fundamental também esclarecer que não existe uma separação rígida entre o cotidiano e o não cotidiano. Segundo Heller (1977), algumas atividades que envolvem o gênero humano relacionam-se, ao mesmo tempo, com as atividades ligadas à vida cotidiana e às esferas não cotidianas.

Tendo posto isso, retornamos a Lukács e a seus apontamentos sobre a cotidianidade e suas relações com as produções humanas. Segundo ele, é na vida cotidiana que se originam a arte e a ciência, formas superiores de recepção e reprodução da realidade. Para ele, a arte é uma atividade que parte da vida cotidiana para, em seguida, a ela retornar, produzindo, nesse movimento reiterativo, uma elevação da consciência dos homens. É um modo de os homens se apropriarem do mundo, 
[...] um peculiar modo de manifestar-se o reflexo da realidade, modo que não é mais que um gênero das universais relações do homem com a realidade, nas quais esta é refletida por aquele. Uma das ideias básicas decisivas desta obra é a tese de que todas as formas de reflexo - das que analisamos antes de tudo a da vida cotidiana, a da ciência e da arte - reproduzem sempre a mesma realidade objetiva (LUKÁCS, 1982, p. 21).

O reflexo estético é a expressão do homem em frente à realidade. É, segundo Foerste (2004, p.37), “o reflexo da realidade social e histórica de que o artista é parte". Ele precisa ser visto não como simples rebatimento da realidade, mas como expressão da sensibilidade do artista, que sofre influências, age e transforma o contexto que integra.

A arte, portanto, reflete a realidade: realidade complexa e multifacetada, compreendida a partir das diferentes esferas que a compõem; realidade referida ao homem inserido em um tempo e espaço concreto; realidade social, uma totalidade viva, na qual se fundem essência e aparência, onde o artista representa o real por meio de sua sensibilidade e das condições que o seu tempo histórico impõe (Foerste, 2004).

O próprio Lukács esclarece dizendo que

[...] o reflexo estético parte do mundo humano e se orienta a ele. Isto não significa nenhum subjetivismo puro e simples. Pelo contrário, a objetividade dos objetos fica preservada de tal modo que contenha todas as referências típicas à vida humana: de tal modo que a objetividade apareça como correspondente ao estágio da evolução humana, externa e interna, que é cada desenvolvimento social (LUKÁCS, 1982, p. 25). 
Nessa visão, o artista é o sujeito capaz de fazer aparecer uma interpretação mais ampla e profunda da realidade. "Capaz de sínteses substantivas sobre a relação dialética entre subjetivo e o objetivo, entre o homem e o mundo" (Foerste, 2004, p. 40). O artista inicia sua criação partindo da realidade, mas, no processo, chega a descobertas mais abrangentes do que as observações medianas oferecidas pela cotidianidade; ele transcende o mundo das aparências.

Ao criar a obra de arte, o artista cria um mundo de leis específicas. $\mathrm{O}$ objeto artístico, então, faz-se uma particularidade capaz de dialogar e interferir nos modos de percepção do seu criador e, consecutivamente, do seu receptor. A arte expressa uma realidade humana em um contexto particular: “É uma representação estruturada da realidade, na qual estão presentes o fenômeno, enquanto manifestação aparente, e a essência, como processo implícito e manifestação das forças sociais atuantes em um dado momento histórico" (Foerste, 2004, p.43).

Assim sendo, a arte abre a possibilidade de o homem encontrar-se com um meio homogêneo, depurado de impurezas e acidentes da heterogeneidade próprios do cotidiano. Na fruição estética, o indivíduo depara-se com a figuração homogeneizadora, mobilizando toda a sua atenção para se adentrar nesse mundo, despojado dos acidentes e variáveis que geram as descontinuidades do cotidiano.

Essa concentração de atenção produz uma elevação do cotidiano, na qual o indivíduo supera a sua singularidade e é posto em contato com o gênero humano. Ou seja, o encontro com a obra de arte torna possível a cada indivíduo reconhecer sua própria essência, sua história no processo de desenvolvimento do ser humano. Como aponta Lukács, ocorre um processo que possibilita aos homens 
[...] a síntese ontológico-social de sua singularidade, convertida em individualidade, com o gênero humano, convertido neles, por sua vez, em algo consciente de si (LUKÁCS, apud FOERSTE, 2004, p. $33)$.

Em sentido mais amplo, podemos considerar, sob a luz do referencial lukcasiano, que o processo de homogeneização envolve a passagem da heterogeneidade da vida cotidiana para a homogeneidade das esferas não cotidianas do gênero humano. Não se trata, portanto, de homogeneizar os indivíduos, anulando suas individualidades. A homogeneização é abordada por Lukács como um processo necessário à relação do indivíduo com as esferas não cotidianas, como a arte e a ciência. Segundo ele, sem a superação da heterogeneidade, que caracteriza as atividades da vida cotidiana, o indivíduo não pode elevar-se, em seu processo de formação, às esferas mais altas da atividade social. Trata-se de um processo que, segundo Heller (1977, p. 117),

[...] é o critério que indica a saída da cotidianidade porém, há que sublinhar, não é um critério subjetivo. Do mesmo modo que a vida individual sem as necessárias formas de atividade heterogêneas não seria uma vida cotidiana que se reproduz, assim as objetivações ${ }^{5}$ genéricas não são reproduzíveis por si mesmas, sem o processo de homogeneização. É precisamente o processo de reprodução das esferas e objetivações homogêneas que exige categoricamente a homogeneização. Se uma sociedade necessita do Estado e do direito, não poderá subsistir nem sequer um dia se não existem pessoas que, por um certo período de sua vida ou durante toda ela, estejam

5 As objetivações são o resultado do desenvolvimento histórico-social. Os indivíduos, ao longo do seu desenvolvimento ontogenético, apropriam-se das objetivações por intermédio da relação com outras pessoas e nelas se objetivam.

Filosofia e Educação [rfe] - volume 7, número 3 - Campinas, SP

Outubro de 2015-Janeiro de 2016 - ISSN 1984-9605 - p. 79-113 
imersas no trabalho sobre a estrutura homogênea do direito e tenham aprendido a pensar sobre tal base. Se uma sociedade necessita das ciências naturais, deve ter um certo número de pessoas que dominem os sistemas homogêneos das disciplinas particulares e aprendam a mover-se neste âmbito, situando-se assim à margem da vida e do pensamento cotidianos [...]. Se estas homogeneizações não se verificam no número e na medida necessários, as necessidades objetivas da sociedade permanecem insatisfeitas e as objetivações não chegam a reproduzir-se. Eis aqui por que a homogeneização não é um critério subjetivo, e não o seria nem sequer se observássemos esse fenômeno - que agora consideramos em comparação com a vida cotidiana - sob a perspectiva do homem singular.

Podemos entender, com a passagem de Heller, que o processo de homogeneização é uma exigência da própria vida e do pensamento cotidiano, pois as esferas não cotidianas da vida social não podem existir sem o processo de homogeneização, assim como a vida cotidiana e com ela a reprodução dos indivíduos não podem existir sem a heterogeneidade das atividades que a compõem.

Lukács (1966) nos esclarece que o poder orientador e evocador do meio homogêneo penetra na vida do receptor, subjugando seu modo habitual de contemplar o mundo, chama a atenção para o mundo, cheio de conteúdos novos ou visto de modos novos, fazendo com que o indivíduo receba esse mundo com sentidos e pensamentos rejuvenescidos, renovados (Lukács, 1966). Esse poder da arte, considerado um meio homogêneo, é o que leva o homem à catarse, compreendida pelo filósofo como "efeito que desencadeia o choque entre o mundo objetivo esteticamente refletido com a mera subjetividade cotidiana" (Lukács, 1966, p. 517, tradução nossa).

É nesse momento catártico que ocorre a transformação do homem in- 
teiro (imerso na cotidianidade) em homem inteiramente receptível à arte, que amplia e enriquece conteúdos e formas, efetivos e potenciais da psique do homem. Traz novos conteúdos que aumentam seu tesouro vivencial, desenvolvem a sua capacidade receptiva e a sua capacidade de reconhecer e gozar novas formas objetivas, novas relações, etc.

A transformação do homem inteiro da cotidianidade no homem inteiramente tomado, que é o receptor em frente a cada obra de arte, move-se precisamente na direção de uma catarse, individualizada e, a mesmo tempo, de suma generalidade (Lukács, 1966). Sobre esse efeito individualizado, o autor coloca que o participante de uma experiência estética não pode ser visto como uma tábua rasa, como um disco gramofônico ainda não gravado em que qualquer coisa poderia imprimir seu efeito. Pelo contrário, Lukács respeita as vivências anteriores do indivíduo, como mostra a citação que segue.

[...] jamais o receptor é uma folha em branco em frente a obra de arte, de tal modo que possa escrever nele cifras quaisquer. O receptor, inclusive quando é criança, chega sempre da vida, carregado de impressões, vivências, pensamentos e experiências que arraigaram mais ou menos firmemente nele a consequência dos efeitos do tempo, da natureza, da classe, etc., e que, às vezes, prontamente, podem se encontrar num estado crítico de transição individual ou social. Pensamos que é correta a nossa expressão anterior segundo a qual o meio homogêneo invade a vida anímica do homem inteiro situado como receptor, e que essa invasão é necessária se tal homem tem que se tornar realmente um receptor estético, um homem que suspende todo outro esforço concreto, se entregando totalmente ao efeito da obra (LUKÁCS, 1966, p. 496-497, tradução nossa).

Com relação ao efeito da obra no receptor, Lukács propõe que, assim Filosofia e Educação [rfe] - volume 7, número 3 - Campinas, SP 
como a relação do homem com os objetos naturais - e seu conjunto - é uma relação ética, o efeito artístico também pode sê-lo, pois, ao se comover pela obra de arte verdadeira ${ }^{6}$, o receptor desencadeia um sentimento negativo, um pesar por não ter percebido nunca, na realidade, na própria vida, o que tão "naturalmente" se oferece na conformação artística.

[...] nessa comoção contém uma anterior contemplação enfeitiçadora do mundo, a sua destruição pela sua própria imagem desenfeitiçada na obra de arte e a autocrítica da subjetividade (LUKÁCS, 1966, p. 507, tradução nossa).

Essa relação ética, submetida ao efeito catártico, é

[...] uma sacudida tal da subjetividade do receptor que as suas paixões vitalmente ativas cobrem novos conteúdos, uma nova direção e, assim, purificadas, se transformem em embasamento anímico de “disposições virtuosas" (LUKÁCS, 1966, p. 508, tradução nossa).

Sendo assim, a arte possibilita ao homem transcender a fragmentação produzida pelo fetichismo da sociedade capitalista. Ela produz uma elevação, uma suspensão da cotidianidade, uma elevação da subjetividade do plano meramente singular para o campo mediador da particularidade que a separa inicialmente do cotidiano para, no final, fazer a operação de retorno à vida, de olhos mais abertos.

Portanto, cada catarse estética é um reflexo concentrado e consciente

$6 \mathrm{~A}$ arte verdadeira ou arte autêntica é a que contém a racionalidade de negação. Em suas condições avançadas, ela é a Grande Recusa - o protesto contra o que é. As maneiras pelas quais o homem e as coisas são levados a se apresentar, cantar, soar e falar [...] essas formas de negação rendem tributo à sociedade antagônica, a qual estão ligadas. Separado da esfera do trabalho na qual a sociedade reproduz a si mesma e sua miséria [...] (MARCUSE, 1973, p. 75).

Filosofia e Educação [rfe] - volume 7, número 3 - Campinas, SP

Outubro de 2015-Janeiro de 2016 - ISSN 1984-9605 - p. 79-113 
produzido de comoções contidas na vida. Segundo o autor húngaro,

[...] a vida trata sempre de um problema ético, o qual, portanto, tem que constituir também o conteúdo central da vivência estética. Mas é claro que, na regulação da vida humana pela ética, a conversão catártica não constitui mais do que um específico caso-limite no sistema das decisões éticas possíveis; junto a ela - por não destacar mais do que uma questão importante - são possíveis resoluções sem emotividade que produzem atitudes éticas tão fortes, duradouras e firmes como as comoções catárticas e, em muitos casos, mais do que estas. É essencial ao ético que a tenacidade consequente seja hierarquicamente superior a todo o entusiasmo, por apaixonado, sincero e profundamente sentido de que este seja (LUKÁCS, 1966, p. 509, tradução nossa).

Em síntese, pode-se concluir que, para Lukács (1966), o efeito catártico desencadeado pela obra de arte é consequência de uma universalidade já plenamente conformada, pois o objeto artístico produz um mundo que não só é particular, ele contém a totalidade das relações sócio-históricas da humanidade. Após a catarse, como diz o autor, no "depois de cada vivência receptiva", o homem é reconstituído, enriquecido, ampliado. Todos os efeitos transformadores se convertem em elemento da vida. Ou seja, a invasão do meio homogêneo converte o homem em receptor propriamente dito, orientando sua capacidade receptiva, proporcionando a esse homem o encantamento do mundo novo, é nesse momento que ele elabora o que adquiriu.

O adquirido é imediatamente conteúdo e, por isso, apresenta ao homem a tarefa de inserir esse conteúdo em sua imagem anterior do mundo, a transformar essa imagem de modo correspondente para 
adaptá-la a àquele. Mas, somente no sentido imediato, trata-se de conteúdo; como este constitui o lado orientado ao receptor de uma identidade forma-conteúdo, o componente formal dessa identidade se manifesta na grande tensão e intensidade do todo, como já sabemos, além do qual a novidade da obra de arte atua também formalmente, na medida em que todo o conteúdo comunica ao receptor algo do método de sua percepção, de sua acessibilidade; por isso a percepção dos novos conteúdos é, ao mesmo tempo, um estímulo e uma orientação para reconhecer também na vida o que lhes é análogo e assim poder apropriar-se do mesmo conteúdo. Desse modo, tem lugar a passagem do homem inteiramente receptivo ao homem inteiro da cotidianidade. É claro que essas comoções e transições são extraordinariamente diversas nos distintos homens, com relação as diversas obras de arte; e a diversidade refere-se ao conteúdo, ao alcance, à profundidade, à duração, etc. O pluralismo da esfera estética desprende-se precisamente nessa multiplicidade. Frequentemente, o efeito de uma obra sobre o Depois do homem é totalmente imperceptível, e faz falta toda uma série de tais agregações para mostrar uma mudança apreciável quanto ao comportamento, cultura, etc.; outras muitas vezes, desde já, basta somente uma obra para provocar uma transformação completa na vida do homem (LUKÁCS, 1966, p. 536-537, tradução nossa).

Em contrapartida, Lukács (1966) alerta para a questão de que até os produtos sem valor artístico, pseudoestéticos, podem ter esses "efeitos", quando saem ao encontro de uma tarefa social de suma importância. Mas seus efeitos não se efetivam, pois eles fixam o indivíduo na imediatidade cotidiana. Cumprem a função de entretenimento. Dirigindo-se à esfera privada dos indivíduos, eles não generalizam, não colocam o indivíduo como gênero e, por isso, o caráter social da personalidade humana não se desenvolve. 
Tendo esse referencial teórico em vista, podemos concluir que o contato com a arte possibilita uma reflexão sobre o mundo, faz com que o homem repense seu cotidiano. Como Lukács (1966) coloca, o homem torna-se inteiro na cotidianidade.

Essa contribuição dada pela arte pode ser mediada e aprofundada com o trabalho educativo. A escola pode contribuir para que os momentos com a arte sejam mais frequentes e significativos. Mas, para que isso ocorra, é preciso que a arte seja entendida em sua dimensão mais ampla. Por isso, o trabalho educativo deve propiciar que o indivíduo conheça a obra de arte em sua totalidade, vista como uma particularidade, em que o momento de catarse está atrelado ao conhecimento de todas as dimensões que a envolvem. Segundo Barbosa (1991, 1997, 2002a), Pillar (1999), Foerste (2004) e Franz (2003), esse conhecimento deve ser iniciado na escola. Então, tendo em vista a relação que liga a catarse ao trabalho educativo, iremos, a seguir, procurar aproximar a categoria catarse à prática pedagógica escolar.

\section{Aproximações da catarse ao trabalho educativo}

Acreditamos que o conceito de catarse seja fundamental para a reflexão sobre o ensino da arte, principalmente no que se refere aos momentos de experiência estética. Se pensarmos que a educação escolar forma os indivíduos para a vida social como um todo, desde a vida cotidiana até as esferas não cotidianas, cabe a ela, em tese, dar condições para que os indivíduos se apropriem das produções científicas e artísticas elaboradas pelo homem. Sabemos que utilizamos, em nosso cotidiano, pragmaticamente, essas construções de saberes e fazeres, mas acreditamos que seja também função da escola proporcionar momentos em que os indivíduos possam se apropriar dessas produções para se reconhecerem como integrantes do gênero humano.

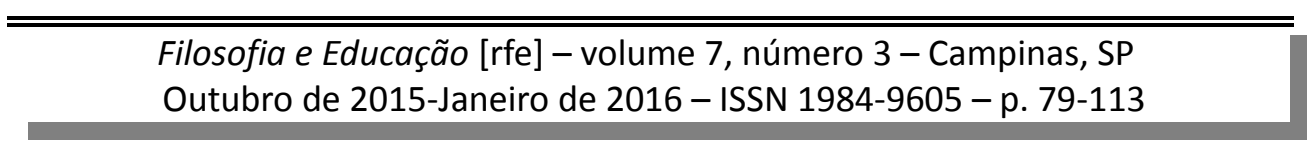


Duarte $^{7}$ (1996) coloca que a categoria de gênero humano não se reduz àquilo que é comum a todos os homens, não é uma mera generalização das características empiricamente verificáveis em todo e em qualquer ser humano, não se trata de desrespeitar a diversidade do indivíduo. Gênero humano é uma característica que expressa a síntese, em cada momento histórico, de toda produção humana até aquele momento. Tomemos as palavras desse autor sobre o assunto.

[...] para se formar como um ser humano, um ser genérico, o indivíduo tem que se tornar um ser social, mas essa socialidade, sendo formada no interior das relações de dominação, implica também o fenômeno da alienação. Lutar contra a alienação é lutar por reais condições para todos os homens de se desenvolverem à altura das máximas possibilidades objetivamente existentes para o gênero humano (DUARTE, 1996, p. 27).

O trabalho educativo é uma das formas de se realizar o processo de homogeneização. É nele que o indivíduo entende as produções do homem e, por conseguinte, reconhece-se como um ser social. Nesse processo, o sujeito passa a entender sua vida de forma menos alienada e, quanto menos alienada for a vida cotidiana, mais ela fornecerá as condições para os momentos em que ocorrem o processo de homogeneização. Isso não quer dizer que, no processo educativo, aconteça a homogeneização de forma espontânea e natural, é preciso que, por meio de mediações, os educandos possam assimilar formas de pensar e agir necessárias a esse processo.

Compartilhamos com Fontana (2005) suas proposições sobre as mediações que ocorrem no contexto escolar, quando ela diz: "Na mediação 7 Compartilhamos as ideias desse autor tendo em vista sua aproximação com a perspectiva histórico-social, bem como com as teorias desenvolvidas por Vigotski.

Filosofia e Educação [rfe] - volume 7, número 3 - Campinas, SP

Outubro de 2015-Janeiro de 2016 - ISSN 1984-9605 - p. 79-113 
do/pelo outro revestida de gestos, atos e palavras a criança vai integrandose, ativamente, às formas de atividade consolidadas (e emergentes) de sua cultura, num processo em que pensamento e linguagem articulam-se dinamicamente" (Fontana, 2005, p.15). Nesse contexto, é preciso que o professor assuma seu papel de mediador, intencional e explícito, estabeleça uma relação de coautoria entre os sujeitos, em que os saberes de alunos e professor interligam-se, criando um espaço em que as "zonas de desenvolvimento iminente" sejam ampliadas pelos dizeres e fazeres de todos. Desse modo, é preciso que as outras pessoas que já adquiriram esse conhecimento atuem sobre o indivíduo no sentido de ajudá-lo a se apropriar conscientemente da arte.

Para tanto, o processo educativo deve colocar o indivíduo em contato com as produções artísticas, científicas, fillosóficas, morais, políticas, etc., realizadas pelo homem ao longo de sua trajetória histórica. Segundo Duarte (1996), na atividade educativa, a relação com o conhecimento científico e sua apropriação por parte do indivíduo é um resultado perseguido de forma intencional e direta. Usando as palavras de Saviani: trabalho educativo é "o ato de produzir, direta e intencionalmente, em cada indivíduo singular, a humanidade que é produzida histórica e coletivamente pelo conjunto dos homens" (Saviani, 1991, p.49). Então, o trabalho educativo ensina o indivíduo a estabelecer uma relação direta, consciente e ativa com o saber científico, proporcionando também o desenvolvimento do pensamento desse indivíduo.

Sendo assim, podemos acreditar que o processo catártico, provocado por uma obra de arte, pode e deve ser proporcionado dentro do trabalho educativo. Nesse sentido, na próxima seção, buscaremos apresentar algumas propostas relacionadas ao ensino da arte na interface escola e espaço expositivo. 


\section{Parceria entre escola/espaço expositivo e o processo catártico}

Atividades que proporcionem o contato e, por conseguinte, a experiência estética a partir de obras de arte, devem acontecer também na escola. Mas, para que isso ocorra, devemos estar atentos ao fato de que propiciar essas experiências por meio de reproduções de obras de arte, não possuem o mesmo efeito que o convívio com originais ${ }^{8}$ de arte (Chisté, 2007).

Cabe, então, pensar em quais possibilidades teríamos para tornar possível o contato com originais de arte. Sabemos que os setores educativos de museus e espaços expositivos têm-se efetivado em muitas cidades brasileiras. Mas percebemos que o simples contato com esses setores que agendam as visitas e definem percursos previamente, e que "monitoram" os alunos sem conhecer suas peculiaridades, não colabora para que a relação com as obras de arte se converta em um processo catártico. O interessante seria que entre esses espaços, escola e espaço expositivo, houvesse uma parceria que proporcionasse vivências estéticas que buscassem desde a preparação até o aprofundamento de tais experiências (Foerste, 2005). Isso implica provocar momentos intensos de encontro com a arte. Esse processo é reiterativo. São idas e vindas pelo espaço expositivo e pela escola, dando continuidade a um ciclo de experiências estéticas que participam da formação sensível e crítica do jovem. Estabelecer parceria entre a escola e o espaço expositivo abarca também firmar uma parceria entre as pessoas que integram tais instituições e buscar alternativas para contribuir com suas práticas pedagógicas.

Assim, é fundamental confirmar a importância dos espaços, escolar e expositivo, como locais que buscam estimular a capacidade criadora do alu-

8 Consideramos o original como a obra que não foi copiada/reproduzida por meios tecnológicos, ao menos que esses estejam inseridos na linguagem utilizada pelo artista em seu processo de criação.

Filosofia e Educação [rfe] - volume 7, número 3 - Campinas, SP

Outubro de 2015-Janeiro de 2016 - ISSN 1984-9605 - p. 79-113 
no, no sentido de proporcionar a esse indivíduo experiências qualitativamente distintas das vividas cotidianamente por ele. É preciso ter claro também que cabe a esses espaços estarem engajados na elaboração de propostas pedagógicas que possibilitem aos alunos o encontro com originais de arte, instigando-os a pensar sobre suas vidas, sobre a arte, a rever suas proposições, seus comportamentos e sua visão de mundo, a buscar, dessa forma, além da conscientização, a apropriação de modos mais sofisticados de analisar e refletir sobre os elementos da realidade. Aliado a isso, é necessário que tais propostas colaborem com a educação do sensível, levando os indivíduos a descobrirem formas inusitadas de sentir e perceber o mundo, apurando seus sentimentos e percepções acerca da realidade vivida.

Para tanto, é necessário considerar que a relação entre obra de arte e receptor implica, necessariamente, uma relação social, uma troca entre sujeitos. Um diálogo tanto com o autor da obra quanto com as vozes sociais que ecoam na obra, e que permitem desencadear um processo reflexivo fundamental na construção social do indivíduo e provoquem reflexões transformadoras sobre estruturas alienantes, manipuladoras e obliteradoras da realidade, proporcionando uma nova atitude diante dos eventos cotidianos. Essa reflexão é fundamental na formação do indivíduo, pois sabemos que nossa sociedade está calcada na espetacularidade dos acontecimentos, em que o espetáculo da realidade, por vezes, substitui a própria realidade. Nesse contexto, um olhar aguçado, aliado a um senso crítico apurado, colabora para o estabelecimento de novas relações com essa realidade e com as diferentes manifestações espetaculares que buscam retratá-la.

As reflexões suscitadas pela obra de arte fazem parte de um contínuo processo de formação e de transformação que colabora com a construção das relações que envolvem o processo de ensinar e aprender arte e que,

Filosofia e Educação [rfe] - volume 7, número 3 - Campinas, SP

Outubro de 2015-Janeiro de 2016 - ISSN 1984-9605 - p. 79-113 
portanto, integram uma proposta de nos desenvolvermos à altura das máximas possibilidades existentes no gênero humano.

\section{Considerações finais}

Neste artigo procuramos apresentar o conceito de catarse a partir da aproximação com alguns autores. A intenção foi explanar as principais ideias de Aristóteles, Vigotski e Jauss sobre catarse, de modo a observar, mesmo que rapidamente, as contribuições e limitações desses estudos. Nosso foco foi traçar um pequeno percurso conceitual da categoria catarse para aprofundar nossas reflexões a partir das ideias de Lukács, e de adeptos ao seu pensamento.

Buscamos aproximar as ideias de Lukács sobre a catarse ao campo da educação, apesar de saber que essa não foi a intenção desse esteta. Contudo, tal aproximação fez-se possível pois buscamos refletir a partir de estudiosos que assumem a base marxiana como referencial teórico relacionado à Educação.

Como se trata de um conceito fundamental para se pensar a formação humana, sobretudo a formação estética, propusemos relacionar o processo catártico ao ensino da arte, promovido tanto pela escola quanto pelo espaço expositivo. Diante dessas ideias pudemos concluir que cabe aos espaços expositivos buscar, em seus setores educativos, aproximar os objetos artísticos do público, efetivar sua função educativa, cultural e social, promover o acesso e à apropriação dos bens culturais constituintes da nossa história. Do mesmo modo, é função da escola, e por conseguinte do ensino da arte, dar condições para que os indivíduos se apropriem das produções científicas e artísticas elaboradas pelo homem.

É responsabilidade desses espaços proporcionar momentos em que os indivíduos possam se apropriar dessas produções para se reconhecerem 
como integrantes do gênero humano, capazes de transformar suas realidades sociais, históricas e culturais. Tais ações integrarão um ciclo reiterativo de processos catárticos.

\section{Referências}

ARISTÓTELES. Poética. Trad. Eudoro de Souza. Lisboa: Imprensa Nacional/Casa da Moeda, 1992.

BARBOSA, Ana Mae. A imagem no ensino da arte: dos anos 80 e novos tempos. São Paulo: Perspectiva, 1991.

__ Arte-educação: leitura no subsolo. São Paulo: Cortez, 1997. (Org.). Inquietações e mudanças do ensino da arte. São Paulo: Cortez, 2002a.

BARBOSA. Tereza Virgínia Ribeiro. A Kátharsis trágica: uma entrega consciente ao desconhecido. In: DUARTE, Rodrigo; FIGUEIREDO, Virgínea; FREITAS Verlaine; KANGUSSU, Imaculada (Org.). Kátharsis: reflexão sobre um conceito estético. Belo Horizonte: C/Arte, 2002b. p. 28-41.

DUAYER, Juarez Torrez. Lukács e a arquitetura. 2003. Tese (Doutorado em Filosofia e Ciências Humanas) - Universidade Estadual de Campinas, Campinas, 2003.

DUARTE, Newton. Educação escolar, teoria do cotidiano e a escola de Vigotski. Campinas: Autores Associados, 1996.

FOERSTE, Erineu. Parceria na formação de professores. São Paulo: Cortez, 2005.

FOERSTE, Gerda Margit Schütz. Leitura de imagens: um desafio à educação contemporânea. Vitória: EDUFES, 2004.

FONTANA, Roseli A. Cação. Mediação pedagógica na sala de aula. Campinas, SP: Autores Associados, 2005.

FRANZ. Terezinha Suely. Educação para uma compreensão crítica da arte. Santa Catarina: Letras Contemporâneas, 2003.

GONÇALVES, Lisbeth Rebollo. Entre cenografias: o museu e a exposição de

Filosofia e Educação [rfe] - volume 7, número 3 - Campinas, SP

Outubro de 2015-Janeiro de 2016 - ISSN 1984-9605 - p. 79-113 
arte no século XX. São Paulo: Editora da Universidade de São Paulo/FAPESP, 2004.

HELLER, Agnes. Sociologia de la vida cotidiana. Barcelona: Península, 1977.

JAUSS, Hans Robert. O Prazer estético e as experiências fundamentais da poiésis, aisthésis e kathársis. In: LIMA, Luis Costa (Org.). A literatura e o leitor. Rio de Janeiro, Paz e Terra, 1979a. p. 63-132.

. A estética da recepção: colocações gerais. In: LIMA, Luís Costa (Org.). A literatura e o leitor. Rio de Janeiro, Paz e Terra, 1979b. p. 43-62.

KONDER, Leandro. O que é dialética. São Paulo: Brasiliense, 1998.

LEÓNTIEV, Alexei Nikolaevich. Artículo de introduccíon sobre la labor creadora de L. S. Vygotski. In: VYGOTSKI, Lev Semenovith. Obras escogidas I. Madri: Visor, 1997. p. 419-450.

LUKÁCS, Georg. Estética 1-La peculiaridad de lo estético. Barcelona: EdicionesGrijaldo, 1966.

. Estética 1 - La peculiaridad de lo estético, 4 v., Barcelona: Ediciones Grijaldo, 1982.

MARCUSE, Herbert. A ideologia da sociedade industrial: o homem unidimensional. Rio de Janeiro: Zahar Editores, 1973.

PILLAR, Ana Alice Dutra. A educação do olhar no ensino da arte. Porto Alegre: Editora Mediação, 1999.

PUENTE, Fernando Rey. A khátarsis emPlatão e Aristóteles. In: DUARTE, Rodrigo; FIGUEIREDO, Virgínea; FREITAS Verlaine; KANGUSSU, Imaculada (Org.). Kátharsis: reflexão sobre um conceito estético. Belo Horizonte: C/Arte, 2002. p. 10-27.

REGO, Pedro Costa. Immanuel Kant e o problema da universalidade do belo. In: SEMINÁRIO INTERNACIONAL ARTE NO PENSAMENTO, 1., Vitória, 2006. Anais eletrônicos. Disponível em: <http://www.artenopensamento.org.br/pdf/immanuel_kant_universalidade_do_belo.p df>. Acessoem: 20 abr. 2006.

Filosofia e Educação [rfe] - volume 7, número 3 - Campinas, SP

Outubro de 2015-Janeiro de 2016 - ISSN 1984-9605 - p. 79-113 
SAVIANI, Demerval. Escola e Democracia. São Paulo, Cortez/Autores Associados, 1991.

VEER, René Van Der; VALSINER, Jaan. Vygotsky: uma síntese. São Paulo: Loyola, 1996.

VIGOTSKI, Lev Semenovich. Pensamento e linguagem. São Paulo: Martins Fontes, 1989. Psicologia da arte. São Paulo: Martins Fontes, 1999.

ZILBERMAN. Regina. Estética da recepscão e a história da literatura. São Paulo: Ática, 1989. 